\title{
EVALUATION ON THE IMPLEMENTATION OF STUDY ON PHYSICAL, SPORT AND HEALTH IN THE PANDEMIC TIME COVID-19 AT SMP NEGERI SE-KOTA SALATIGA TAPEL 2020/2021
}

*Sanfia Tesabela Messakh, Budi Utomo, Fatkur Rohman

Correspondence: Program Studi Pendidikan Jasmani Kesehatan dan Rekreasi, Universitas Kristen Satya Wacana, Indonesia E-mail: andi.nurabady@gmail.com

\begin{abstract}
The Ministry of Education and Culture of the Republic of Indonesia issued a policy to temporarily close educational activities held in schools. This policy resulted in several changes and caused a transition in the process of implementing PJOK learning. The purpose of this study is to describe the evaluation of the implementation of physical education, sports and health learning in State Junior High Schools in Salatiga during the Covid-19 pandemic. This research uses qualitative methods with a descriptive approach. The data analysis technique in this study used the Analysis Interactive Model technique from Miles and Huberman. The results of the study indicated that PJOK teachers were obliged to make learning tools such as syllabus, lesson plan (RPP), semester program (Promes) and annual program (Prota). The implementation of online learning is carried out using various internet-based applications including Google Classroom, Google From and WhatsApp (WA) as the main communication media for teachers and students for learning reminders and assignments. Learning assessments during the Covid-19 pandemic are designed to encourage meaningful learning activities for students in the form of assignments and teacher observations of students during the online learning process.
\end{abstract}

Keywords: Physical Education, Covid-19, Evaluation Of Learning

\section{Introduction}

Education is a coaching process that has a very important role in human life. Education is not only about aspects of knowledge, but all dimensions of human life, both aspects of knowledge, attitudes or behavior and skills. Education in Indonesia is divided into three channels, namely informal education, non-formal education and formal education. Informal education is an educational path that is obtained from the family (father, mother, brother and sister), the community and the local environment. Non-formal education is a structured and tiered education pathway that takes place in the community, such as computer courses and English language courses which can be found through home schooling activities and the

PJKR 
Teaching and Learning Activity Center (PKBM). Formal education is education made by the government in a structured, systematic, graded or tiered, consisting of basic education to higher education (Jamrah, 2016).

Physical Education, Sports, and Health (PJOK) is an integral part of the formal education that is held in schools. The objectives of PJOK are the same as the goals of education in general, namely to develop the potential of students in the aspects of knowledge, attitudes, and skills through physical activities, games, and sports (Lauh, 2016). Through physical activities, games, and sports presented in PJOK, it is hoped that students can gain many valuable experiences for life, namely cooperation, emotional, intelligence, caring, creativity, good quality of life, movement skills which include locomotor, non-locomotor and manipulative (Utama, 2011). The process of implementing physical education, sports, and health learning that is held in schools is usually carried out through physical activities, games, and sports directly (face to face) or face-to-face learning between teachers and students (Kastrena et al., 2020).

The process of implementing learning is a process of interaction carried out by teachers with students and between students in a learning environment to achieve predetermined learning goals (Zuharon, 2017). To find out the success or failure of the learning process, a teacher must evaluate the learning outcomes. Evaluation of conventional physical education learning outcomes is carried out through observations during the learning process. During the learning process, a teacher can evaluate thoroughly, both in the aspect of knowledge regarding the understanding of students about the learning material that has been carried out, as well as in the aspect of attitude when students socialize, interact, and

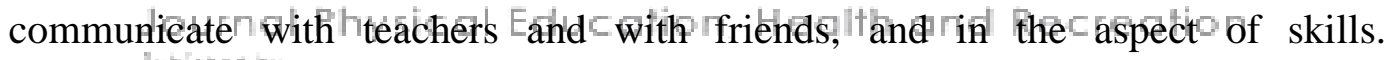
movements performed by students (Kasriman, 2016). During its development, physical education, sports and health have changed. This change was caused by changes in student learning methods due to the Covid-19 pandemic that is currently sweeping the world, including Indonesia.

Covid-19 is a disease that attacks the human respiratory system, which is caused by the Corona virus or Severe Acute Respiratory Syndrome Coronavirus 2 (SARS-CoV-2). This virus outbreak initially developed in Wuhan China, in December 2019. Within a few months, to be precise on March 10, 2020, the confirmed number of Covid-19 cases in China was 80,761 positive cases, 3,136 deaths, and 4,794 critical cases (Rumbo, 2020 ). According to the World Health Organization (WHO), the Corona virus can be transmitted through small droplets from a person's mouth or nose when an infected person coughs or sneezes. In general, people affected by the Corona virus suffer from mild symptoms such as 
fever, sore throat, runny nose, and cough (Yezli \& Khan, 2020). The transmission of the Corona or Covid-19 virus outbreak has spread very quickly to various countries in the world. During the period 10 June 2020, there were 7,094,047 positive cases and 406,461 deaths worldwide due to Covid-19 (Negeri, 2020).

Indonesia first confirmed the Covid-19 case on March 02, 2020 (COVID19, 2020). On June 10, 2020, there were 34,316 positive cases of Covid-19 and 1,959 deaths in Indonesia (Negeri, 2020). The Covid-19 pandemic initially caused disruption in the social sector, the economic sector which has begun to decline, but now its impact is also being felt in the education sector. One of the efforts made by various countries including Indonesia in preventing and breaking the chain of the spread of the Corona virus is by implementing a policy in the form of an appeal to carry out physical distancing. The Ministry of Education and Culture of the Republic of Indonesia issued a policy to temporarily close educational activities held in schools. This policy has resulted in several changes and causes a transition in the process of implementing PJOK learning (Purwanto, et al., 2020).

The process of implementing PJOK learning which was previously carried out face-to-face in schools is now being replaced by online learning or distance learning (Kastrena et al., 2020). Face-to-face learning is a learning activity in the form of interaction between teachers and students and learning resources in a learning environment. The process of implementing face-to-face learning has several advantages and disadvantages. The advantages of face-to-face learning are that it can make it easier for a teacher to provide reinforcement to students, facilitate interaction and the assessment process, can form mental discipline, and teachers can observe the behavior of students in receiving learning material directly (Khâsanah et al., 2020) The drawbacks of face-to-face-learning are that it makes students bored because the learning is very monotonous, creates rigidity in learning, and reduces the initiative and creativity of teachers in using learning methods and media (Husamah, 2015).

During the current Covid-19 pandemic, the process of Teaching and Learning Activities (KBM) in schools uses an online system based on "Minister of Education and Culture Circular No.4 of 2020 concerning the Implementation of Education Policies in an Emergency Period of the Spread of Corona Virus Desease (Covid-19) ". Online learning is learning that is carried out using technological media such as devices, laptops, and computers as well as an internet network (Firman \& Rahman, 2020). The implementation of online learning has a positive impact. Online learning is considered very flexible and provides flexibility for students to find and get other references in increasing their knowledge related to learning materials. For teachers, online learning is useful for

PJKR_ 
increasing teacher creativity in using various learning methods and models in delivering learning material (Reza, 2020). The added value of online learning can improve the ability of students and teachers to use and access technology (Rachmat \& Krisnadi, 2020).

Distance learning also has several problems or constraints for teachers and students such as lack of adequate facilities and infrastructure, spending costs to buy internet quotas, lack of internet access, not being used to conducting online teaching and learning activities, difficulties of students in receiving the material presented, and there are still many teachers who are not proficient in using technology in the process of implementing learning as well as teacher obstacles in assessing or evaluating learning outcomes for students (Rigianti, 2020). This is a new challenge for students and teachers in implementing online learning during the Covid-19 pandemic.

Distance learning also has several problems or constraints for teachers and students such as lack of adequate facilities and infrastructure, spending costs to buy internet quotas, lack of internet access, not being used to conducting online teaching and learning activities, difficulties of students in receiving the material presented, and there are still many teachers who are not proficient in using technology in the process of implementing learning as well as teacher obstacles in assessing or evaluating learning outcomes for students (Rigianti, 2020). This is a new challenge for students and teachers in implementing online learning during the Covid-19 pandemic.

\section{Method}

This study luses a iqualitative method withat descriptive approach that aims to describe and assess the results of the evaluation of the implementation of PJOK subjects during the Covid-19 pandemic at State Junior High Schools in Salatiga City. This research will be conducted at State Junior High Schools (SMP) in Salatiga City and will be carried out in July - September 2020. This research describes the evaluation of the implementation of PJOK learning during the Covid-19 pandemic, both in terms of learning planning, learning implementation and learning assessment. Respondents in this study were teachers of Physical Education, Sports and Health (PJOK) class VIII (Eight), totaling 10 people from 10 State Junior High Schools in Salaltiga City.

Data collection techniques in this study using interview and documentation methods. Interviews are conducted through questions that lead to depth of information. The documentation method is used to complement the data and evidence in this study. The data analysis technique in this study used the Analysis 
Interactive Model technique from Miles and Huberman. The Analysis Interactive Model technique is carried out in several stages, namely, collecting data, reducing data, presenting data, and concluding data (Miles et al., 2013).

\section{Result and Discussion \\ Planning}

Before carrying out Teaching and Learning Activities (KBM), Physical Education, Sports and Health (PJOK) teachers are obliged to make learning devices such as syllabus, lesson plans (RPP) and several other tools to support the implementation of learning such as the Semester Program (Promes) and the Annual Program. (Prota). The lesson plans used during the Covid-19 pandemic are different from the lesson plans made offline because teachers have to adjust learning to existing conditions. This is in accordance with the Circular of the Minister of Education and Culture (Mendikbud) of Indonesia No.14 of 2019 concerning Simplification of the Learning Implementation Plan that the components that must be included by teachers in preparing RPP are learning objectives, learning steps, and assessment of learning outcomes. This component is a core component in preparing the RPP during the Covid-19 pandemic (Indonesia, 2019). Other RPP components such as school identity, subject identity or theme / sub-theme, class / semester, subject matter, time allocation, basic competencies and achievement indicators, learning materials, learning methods, learning media and learning resources as regulated in Mendikbud Number 22 2016 is only complementary (Permendikbud, 2016). Therefore, a teacher is given the freedom to choose, use, and create and develop in the preparation of a lesson plan.

Based on the results obtained by researchers, it can be seen that in the preparation of RPPs during the Covid-19 pandemic there were 8 out of 10 PJOK teachers in State Junion High' $\mid$ Schools $\mid$ indSalatiga Cityewho added fand rincluded several components that were considered very important in order to achieve online learning goals. . The components included include learning materials, learning methods, and learning media. To achieve learning objectives during the Covid-19 pandemic, PJOK teachers must be able to organize learning material into something more meaningful so that students easily accept and understand learning material. Teachers of PJOK SMP Negeri in Salatiga City stated that online learning materials were made not only easy to understand, but of course the material could be done or practiced by students in their respective homes. According to Kurniasari, (2020) in online learning preparation a teacher is required to be able to design creative and effective learning that is easily understood by students by utilizing appropriate learning media in accordance with the material to be delivered.

The materials that have been taught at State Junior High Schools in Salatiga, especially PJOK material, are Physical Fitness, Physical Activity, Rhythmic Gymnastics, Floor Gymnastics, First Aid (First Aid for Accidents), Pencak Silat,

PJKR_ 
Athletics, and Big Ball (Basketball, Volleyball)., and Football). The main principle in providing learning material during the Covid-19 pandemic is material oriented towards students including life skills education, learning for experiences, health, and varied learning activities and promoting good response or feedback between teachers and students through utilization of learning media (Culture, 2020). In addition to learning materials, it is no less important for the implementation of learning to run well is the use of appropriate learning methods. The learning method applied is different from the learning activities carried out during face-to-face learning in schools. The learning method for PJOK at State Junior High Schools in Salatiga City during the Covid-19 pandemic was carried out through the E-Learning method or through providing home assignments that had to be completed by students by utilizing information and communication technology. E-Learning is a transformation effort or a new way in the teaching and learning process in schools that utilizes electronic media, especially the internet as a learning system (Imania \& Bariah, 2019).

Based on the results of interviews with PJOK teachers, the delivery of learning materials during the Covid-19 pandemic used lecture and demonstration methods. The lecture method used by PJOK teachers to explain learning/material orally to students using online learning media where the material has been summarized in the form of Power Points. Meanwhile, the demonstration method was used by PJOK teachers during the Covid-19 pandemic to clarify a learning topic by showing a process in demonstrating or practicing a movement to students. An explanation of this movement is given through a video tutorial shown by the PJOK teacher himself or a video taken from the Yootube channel. The use of videos is very useful for clarifying learning material, attracting students 'interest in learning and for increasing students' understanding. Batubara \& Batubara, (2020) states that the use of video as an online learning medium is very effective in increasing understanding, clarifying material and increasing the learning independence of students. In addition, the results of research by Sutrisno \& Pratama, (2020) also show that students' responses during online learning are very good for the use of instructional video tutorials. The selection of learning methods is of course adjusted to the material to be taught and the characteristics of each indicator of learning competency achievement. Through the application of online learning, the most important thing in choosing an online learning method is that teachers must be able to adjust to using various online learning media by paying attention to the situation and conditions that are happening (Dwi et al., 2020).

At this stage of online learning preparation a teacher is forced to be "literate" about technological advances. Learning can be carried out with a supporting media, namely using information and communication technology such as portable computers and devices that are equipped with various internet-based applications (Umam Syaiqul, 2020). For this reason, teachers must be able to create or design a new learning innovation by utilizing online learning media. The skills of teachers in utilizing a learning media can motivate students to be enthusiastic and active in participating in learning (Kurniasari, 2020). Therefore, educators or teachers are

PJKR_ 
required to be more creative in preparing and designing the best possible learning in order to realize effective and efficient learning as well as fun for students. The change in the learning system, from conventional learning to online learning, indirectly makes teachers need time to adapt to these changes (Purwanto et al., 2020). Based on the results of interviews obtained by researchers, the PJOK teacher stated that he had to learn more in making and simplifying material using attractive technology media so that students were enthusiastic about taking part in learning. Surahman et al., (2020) stated that not all teachers are proficient in using internet-based information and communication technology as a means of supporting learning activities during the Covid-19 pandemic. Therefore, a teacher needs mentoring, support and training first to increase his or her competence in the use of appropriate learning tools, strategies, models and distance learning methods (Syahroni et al., 2020).

\section{Implementation}

Self-limitation in accordance with policies issued by the Central and Local Governments causes students not to be allowed to physically attend school. Even so, learning activities must continue with a choice of online models using various internet-based applications. From the results of in-depth interviews with PJOK teachers conducted at State Junior High Schools in Salatiga, the researcher explained that online learning applications that are often used by teachers and students are very diverse. The applications used by PJOK teachers to support online learning include Prakasita Classroom, Moodle LMS, Google Classroom, Microsoft Teams, Zoom Meeting, WhatsApp (WA) and Google From.

The most dominant online learning media used by PJOK teachers in Public Junior High Schools in Salatiga are WhatsApp (10 teachers), Google From (6 teachers) and Google Classroom (6 teachers). The WhatsApp (WA) application is used by PJOK teachers as the main communication media for teachers with students for learning reminders and assignments for students, a forum for asking questions for students, collecting assignments, and providing practical videos during the Covid19 pandemic. The WhatsApp (WA) application is one of the most popular communication media today, because it is very easy to use. Anhusadar, (2020) states that the WhatsApp application is very easy to use, saves internet quota, is not complicated and not too difficult when the signal is weak or not supportive. Through the use of the WhastApp application, teachers can also provide various information via text messages, voice, voice and video calls and can send assignments to students in various formats such as Microsoft Power Points, Microsoft Word, PDF, and video links (Rigianti, 2020).

During the online learning process, PJOK teachers at Junior High Schools in Salatiga use Google From media to give assignments to students. The assignments given are in the form of essay questions, objective questions such as a fill-in test, true-false, and multiple choice questions. The Google Form is also often used by teachers as a medium for digital student presence. Apart from being easy to use and accessible, Google Form also offers services for creating surveys with a

PJKR_

https://jurnal.unimed.ac.id/2012/index.php/jpehr 
variety of questions that can be tailored to your needs (Rachmat \& Krisnadi, 2020). Anugrahana, (2020) states that practicing questions through Google Form can increase the enthusiasm of students because the results of the work and the correct answers can be seen directly by them.

Google Classroom provides various learning features that can be used easily so that there are many users. Through Google Classroom, teachers can create innovative and creative teaching for students. In addition, Google Classroom also allows for effective and efficient online communication between teachers and students and between students. The teacher can give announcements to students about learning activities, assignments and direct learning evaluations. On the other hand, students can provide feedback and share material and interact with one another easily (Endah Wulantina, 2019). Ningsih (2020) states that online learning through Google Classroom is able to increase interaction between teachers and students and between students in the learning process, which makes accessing and communicating using this application very easy. The use of this application is carried out to deliver teaching materials in the form of lectures, discussions and demonstrations. In addition to these applications, PJOK teachers use the Microsoft Power Point application to make it easier for students to understand the learning material to be delivered.

Based on the results of interviews with PJOK teachers, the duration of teaching at State Junior High Schools throughout the City of Salatiga during the Covid-19 pandemic period lasted 60 - 120 minutes per face-to-face. To further maximize understanding of PJOK material for students, teachers do not only rely on conventional methods such as requiring students to read textbooks owned by students, do practice questions through Student Worksheets (LKS) or given material based on teacher handbooks. Along with technological advances, teachers also make use of information media such as the internet and Youtube as a source of learning material for students. The teacher will provide a video link related to PJOK material that is relevant to the material being taught and is available on the Youtube channel for students to watch and learn. Students are also asked to read certain articles related to PJOK material as learning reference material or make a summary of certain material based on information that can be found via the internet. According to Ririn Puspita et al., (2020), technological advances have made learning media more developed so that media such as the internet and Youtube are often used or used by teachers as an alternative in the learning process which can be accessed by students anytime and anywhere.

Teachers of Physical Education, Sports and Health at Public Junior High Schools in Salatiga City also have a forum for communication between PJOK teachers, which is better known as MGMP PJOK, especially in the Semarang Regency area who are members of the WhatsApp (WA) group. MGMP (Subject Teacher Deliberation) is a professional communication forum for subject teachers in an area to be used as a place for teachers to discuss with each other, provide assistance and feedback and share experiences (Educator, 2008). Through this communication forum, teachers can share information about various matters

PJKR_

https://jurnal.unimed.ac.id/2012/index.php/jpehr 
related to learning to support the provision of PJOK material for students. This is in line with what the Educators stated, (2008) that the purpose of the MGMP is to broaden the teacher's insight in mastering learning materials, compiling syllabus, compiling learning materials, maximizing the use of learning media by using strategies, methods and utilizing good learning resources improve the quality of the education and learning process in a sustainable manner.

The advancement of the use of information and communication technology in implementing online learning has the advantage that it is not hindered by space and time. The implementation of online learning allows teachers to create material and provide explanations of teaching materials that can be accessed by students anytime and anywhere (Anhusadar, 2020). According to Anhusadar, (2020) the creativity of a teacher in carrying out learning is also increasing because teachers can innovate using a variety of very varied learning methods. Another advantage of online learning is that it can increase the interest and learning independence of students and increase the creativity of students in using learning media (Rachmat \& Krisnadi, 2020). Online learning is more student-oriented or centered which can enable them to foster a willingness to learn, be creative, think critically in solving problems and take responsibility for their own learning. According to Sadikin \& Hamidah, (2020) online learning can increase students' interest in learning. Online learning requires students to prepare, search, organize, evaluate and motivate themselves in learning. However, apart from the advantages of changing learning methods and systems, online learning also has several obstacles or drawbacks. The process of implementing this online learning is something that is new to be done and felt by teachers and students. Therefore, teachers and students need time to adapt to these changes.

The main obstacle that hinders students from following the learning process online is inadequate facilities and infrastructure. Based on the results of the interview, out of 10 Public Junior High Schools in Salatiga, there are some students who still do not have portable computers and even do not have personal devices. Even though the media is the main supporting factor in implementing online learning. According to Purwanto et al., (2020) online learning facilities such as portable computers, devices and computers are very important to support the implementation and smoothness of the online teaching and learning process. Therefore, online learning facilities and infrastructure should be provided first so that students can easily follow and listen to the teaching and learning process online.

Another obstacle that is often experienced by students and teachers of State Junior High Schools in Salatiga is the network (signal). Sometimes learning activities are virtually interrupted because the signal is lost so that communication is cut off. Oktawirawan, (2020) states that the lack of internet access in certain areas is one of the factors inhibiting the process of implementing online learning. In addition, parents' expenses increase because they have to buy pulses or data packages for the learning needs of students. Household expenditures for children's learning needs to purchase internet quotations per month vary, ranging from Rp. 60,000 to

PJKR

https://jurnal.unimed.ac.id/2012/index.php/jpehr 
Rp. 100,000. Purwanto et al., (2020) stated that online learning using technology media requires a network connection to the internet so that the increase in students' internet quota usage to take part in online learning will increase and will have an impact on increasing parental expenses.

The process of implementing online learning also has special challenges. Based on the results of interviews obtained by researchers from PJOK teachers, that the existence of a separate place or location when carrying out online learning causes a PJOK teacher at SMP Negeri in Salatiga City to experience difficulty in coordinating students and directly supervising the activities carried out by students during the learning process. . Some teachers do not know whether students really pay attention and listen to the material presented. Szpunar et al., (2013) suggest that students think about other things more often (fantasizing) during online learning compared to conventional learning. Therefore, online learning should be carried out in a not too long time considering that students easily lose their concentration.

Over time, the active or enthusiastic participation of students in participating in online learning is decreasing from day to day (Cahyani et al., 2020). School holidays that are too long make students start to feel bored and bored so that students are no longer active in participating in learning. The learning process will be successful if students are motivated to learn (Arianti, 2019). Therefore, teachers must be creative in arousing or fostering learning motivation of students so as to obtain optimal learning outcomes. PJOK teachers at State Junior High Schools in Salatiga are making great efforts in overcoming this problem. Based on the results of the interviews obtained by researchers, one of the efforts made by PJOK teachers in State Junior High Schools in Salatiga during online learning was to provide motivation in the form of enthusiastic words for learning that were given orally or in writing in each learning process. The teacher also displays or shows one of the student's video assignments that are considered very good and good in order to motivate students to remain enthusiastic about participating in learning. Another effort made by the teacher so that students are active in participating in online learning is by asking students in turn to read and explain the material displayed by the teacher during learning according to their understanding and asking scramble questions that are easily answered by students. In line with the results of Emda's research, (2018) which states that, the teacher's efforts to foster and increase student motivation are to clarify learning objectives, create a pleasant learning atmosphere, give praise for the success of students, motivate students by using a variety of models. and attractive strategies, creating competition between students in learning and providing assessments to students.

\section{Assessment}

Assessment is a comprehensive or continuous effort regarding the learning outcomes that students have achieved through the process of teaching and learning activities that have been implemented (Imania \& Bariah, 2019). The PJOK assessment refers to three aspects, namely aspects of knowledge, attitudes, and

PJKR_

https://jurnal.unimed.ac.id/2012/index.php/jpehr 
skills. There are various assessment methods that can be selected by teachers that are relevant to learning objectives such as attitude assessment (Teacher Observation, Homeroom Observation, Self-Assessment, Inter-Peer Assessment), assessment knowledge (written tests, oral tests, assignments), and skills assessments (Practices, Products, Projects and Portfolios) (Kemendikbud, 2017). According to Çelik et al., (2018) the assessment was carried out to determine the extent to which students understand the material that has been given by a teacher and to increase the effectiveness of learning. Therefore, a teacher must conduct an assessment in order to obtain information about the achievement of student competencies.

Based on the results of interviews with PJOK teachers, the implementation of assessments at State Junior High Schools in Salatiga City was obtained from assignments such as quizzes, daily tests, teacher observations of students, and project making or students' creativity in completing practical tasks (video). Daily quizzes or tests are conducted by PJOK teachers to assess aspects of students' knowledge. The assignments given are in the form of essay questions, objective questions such as a fill-in test, true-false, and multiple choice questions. Assessment in the aspect of student attitudes during online learning is carried out through observations or observations of the PJOK teacher when the learning takes place. This assessment is seen from the activeness of students such as responding quickly, always asking questions and often answering questions raised by the teacher during the learning process. In addition, the assessment of students' attitudes is also seen from the discipline and responsibility of students in following learning from beginning to end and collecting assignments that have been given on time.

Regarding the aspect of assessing the skills of students, the PJOK teacher assesses by looking at the project creation or the creativity of students in completing the learning practice (video) that has been submitted according to the material that has been taught. Through this assignment, the PJOK teacher will assess the skills of students from the aspect of truth in doing or practicing a movement. The average collection of student assignments is collected through the media Google Form, WhatsApp (WA) and Google Classroom. The values that have been obtained will be recapitulated together and then calculated to be used as student report cards. Thus, it can be concluded that during online learning, PJOK teachers at State Junior High Schools in Salatiga City continue to assess students.

Assessments for student advancement conducted online are designed to assist and encourage meaningful learning activities for students, not to determine the importance of values or standards for achieving curriculum completeness as a whole (Dwi et al., 2020). The change in the learning system from conventional learning to online creates new problems for teachers in terms of student assessment (Rigianti, 2020). Based on the results of the interview, the obstacle for PJOK teachers at Public Junior High Schools in Salatiga City in conducting assessments during online learning was that many students did not collect assignments on time and did not even do the assignments at all. In addition, 
teachers also have not been able to bring up the attitudes of students in online learning such as honesty of students and cooperation between students.

In general, the assessment of PJOK subjects when face to face is carried out directly, such as conducting an evaluation at the end of the implementation of learning by asking questions to students about the material that has been studied and paying attention to the behavior of students during the learning process and seeing the learning movements practiced by the participants. students (Hariadi, 2018). PJOK teachers usually conduct attitude assessments naturally when students communicate and interact both with teachers and with friends during the learning process at school. Rigianti, (2020) states that there is enforcement to carry out learning online, a teacher cannot monitor students as a whole due to different locations and directly eliminates socialization and interaction between students in schools so that it becomes an obstacle for teachers to conduct attitude assessments. learners. Related to the delay in collecting assignments is also an obstacle for teachers to assess the knowledge and skills of students. Anugrahana, (2020) states that the lack of online learning facilities and infrastructure that students have such as portable computers, devices, and internet network problems in several places is an inhibiting factor for students in collecting assignments. From these problems, a teacher needs to conduct an evaluation so that the predetermined online learning objectives can be achieved.

\section{Evaluation}

Learning evaluation is the process of gathering information about learning activities that have been implemented (Nuriyah, 2014). Learning evaluation is carried out to assess the extent of the teacher's success in designing and implementing a learning program and knowing the level of understanding or achievement of students regarding the learning material that has been delivered (Asrul et al., 2014). Therefore, the existence of teacher evaluation can determine the effectiveness and efficiency of a learning program that is useful for teachers to be used as material for reflection in making the next learning program. Based on the data and the results of the interviews that the researchers have described from the preparation, implementation and assessment stages above, the process of implementing PJOK learning during the Covid-19 pandemic which was carried out online at State Junior High Schools throughout the City of Salatiga had several impacts or obstacles for teachers and learners. For this reason, PJOK teachers need to evaluate learning so that the implementation of subsequent online learning runs optimally.

Based on the results obtained by the researcher, the obstacle in the preparation stage for online learning at State Junior High Schools in Salatiga is the lack of ability and skills of PJOK teachers in operating or using internet-based technology media to support the implementation of online learning. Purwanto et al., (2020) stated that online learning requires teachers to improve their abilities, especially creativity in using and operating online learning media as best as possible. The ability and skills of teachers in using online learning support

PJKR_

https://jurnal.unimed.ac.id/2012/index.php/jpehr 
technologies greatly affect the quality and learning outcomes of students (Mastura $\&$ Santaria, 2020). Therefore, a teacher needs assistance and support through training or webinars to improve his competence in designing online learning as attractive as possible in order to achieve the expected learning goals (Purwanto et al., 2020).

Manora, (2019) states that one of the components of education that has an important role in improving the quality of education is the principal. The role of school principals is currently crucial to encourage and assist teachers in increasing innovation and learning creativity during the Covid-19 pandemic. The first effort the principal must make is to meet the needs of PJOK teachers, such as improving facilities and infrastructure to support online learning. Educational facilities and infrastructure are all devices or facilities used in the learning process so that the achievement of learning objectives can run effectively and efficiently (Tamara, n.d.). Improved facilities and infrastructure can be useful for teachers as a supporting factor for the implementation of the teaching and learning process to achieve learning objectives (Annisa, 2019). Purwanto et al., (2020) also stated that online learning facilities such as portable computers, devices and computers as well as the availability of a good internet network are very important to support the implementation and smoothness of the online teaching and learning process.

The second effort that the principal must make is to collaborate with providers to provide training on appropriate training, strategies, models and methods of distance learning through training activities or webinars to improve the quality of teacher competence in implementing online learning. Manora, (2019) states that one of the roles of the principal is to manage education personnel in improving their professional abilities and skills. This effort can be done through good collaborative relationships for the professional development of teachers by facilitating and providing opportunities for teachers to participate in various educational activities, training or webinars, both held at school and outside of school (Mukhtar, 2015). Through these efforts, teachers can be motivated to be enthusiastic about increasing their competence in exploring or designing online learning in an attractive and systematic manner in order to achieve the expected goals.

Changes in the learning system from conventional to online learning also provide several obstacles for teachers in the learning implementation process. Based on the results of interviews with PJOK teachers, the obstacles when carrying out online learning at Public Junior High Schools throughout the City of Salatiga are the lack of personal devices of students, the problem of internet networks that are not evenly distributed in several places, students easily lose their concentration, wasteful spending on quota costs, the difficulty learning conditioning, the lack of involvement of students in participating in learning, and the boredom of students while participating in learning.

Online learning is carried out to provide meaningful experiences for students, without having to complete all curriculum achievements (National, 2020). In the implementation of online learning, it is better if PJOK learning is 
carried out with a maximum duration of one hour at each meeting so that students stay focused on following learning. In line with Khan's research, (2012) which states that students find it difficult to maintain their concentration if the implementation of online learning is held for more than one hour. The concentration of students during online learning is easily lost because of the many disturbances when the learning process takes place such as devices, games, family problems and $\mathrm{TV}$, which causes the ineffective learning process from home (Kurniasari, 2020).

The learning material to be delivered in the form of Power Points or video conferences must also be more concise, clear, varied, and fun by using language that is easily understood by students. To improve the quality of online learning, learning materials should be presented in a concise, clear, varied and fun way using attractive learning media so that students can easily understand the material and online learning objectives can be achieved (Kurniasari, 2020). This was done to minimize wasteful spending on internet quotas and make students stay concentrated in following learning. Efforts to improve the quality of learning during the Covid-19 pandemic, teachers can use the Problem Based Learning model which is implemented in the discussion system, both group discussions and class discussions. According to Sarifudin \& Hanif Evendi, (2018) the Problem Based Learning model is a student-oriented model. The Problem Based Learning model provides opportunities freely for students to develop skills in solving problems by proposing ideas, thoughts, opinions or criticisms. Mohammad Yazdi's research results, (2012) show that through the online discussion method, students and teachers can interact and communicate via the internet so that they can add knowledge and broader insights. Therefore, the Problem Based Learning model can be used as an alternative model to increase the involvement and activeness of students in online learning.

Kemdikbud, (2020) argues that, to improve the quality and success of online learning during the Covid-19 pandemic, it is necessary to have comprehensive cooperation from all parties, including government, schools, teachers, parents, health services and civil society. The central and local governments work together to formulate and provide learning policies that are in favor of students. Schools provide and facilitate online learning activities using appropriate methods. A teacher must continue to improve his competence to be able to carry out interactive learning. The active role of parents to participate in the learning process at home. Health services monitor risks in the regions in order to prioritize the health of students. Communities and social institutions together help to support student activities.

Learning assessment is an integral part of teaching and learning activities to obtain information about the level of achievement of students (Rigianti, 2020). Based on the results of interviews obtained by researchers from PJOK teachers, the process of assessing students during the Covid-19 pandemic at State Junior High Schools in Salatiga City experienced problems because many students did not collect assignments on time and did not even do the assignments assigned by

PJKR_

https://jurnal.unimed.ac.id/2012/index.php/jpehr 
the teacher. The existence of different places and the lack of facilities that students have is one of the factors that hinders students from collecting assignments (Anugrahana, 2020).

Giving assignments in the form of practice questions or practical video assignments of a movement was felt to have been done during the Covid-19 pandemic. However, giving too many and the same tasks continuously sometimes feels boring for students. Kurniasari, (2020) states that students are very burdened because the tasks given during online learning are very many, monotonous, and the deadlines for collecting assignments are too fast so that it is burdensome for students to do them. Therefore, the teacher must provide a variety of assignments in order to increase the willingness of students to do it. Giving assignments should not be too much so that students do not feel too burdened by the assignment of these assignments. In addition, giving assignments to students during online learning must be very clear and the assignments to be given should be easy and fun to do.

For example, the teacher can assign students to make an experiment such as modifying sports equipment using materials or media that can be used and easily found at home. The teacher can also give assignments that involve the families of students in completing their tasks, such as making simple video conversations about materials that are related to physical education learning, sports and health as well as conditions that are currently being experienced. This is in accordance with the Circular of the Minister of Education and Culture No.4 of 2020 concerning the Implementation of Education Policies in the Emergency of the Spread of Corona Virus Desease (Covid-19) which states that, online learning is carried out to provide meaningful learning experiences for students, the learning can be focused on skills life and activities and online learning tasks can vary according to interests, conditions and gaps in access or learning facilities of students at home.

\section{Conclusions and Suggestions}

Conclusion The implementation of online learning for Physical Education, Sports and Health subjects in Public Junior High Schools in Salatiga City during the Covid19 pandemic currently includes the stages of preparation, implementation and assessment of learning. The preparations made include the making of a syllabus, a lesson plan (RPP), a Semester Program (Promes) and an annual program (Prota). At the learning implementation stage, teachers use various internet-based applications including Google Classroom, Google From and WhatsApp (WA) as the main communication media for teachers and students for learning reminders and assignments. Learning assessment during the Covid-19 pandemic was not designed to determine standards for achieving curriculum completeness as a whole but to encourage meaningful learning activities for students in the form of assignments and teacher observations to students during the online learning process.

The suggestions that researchers can convey regarding online learning during the Covid-19 pandemic are as follows: (1) In the learning preparation stage

PJKR_

https://jurnal.unimed.ac.id/2012/index.php/jpehr 
during the Covid-19 pandemic, the principal should be able to encourage teachers to improve their competence in exploring or designing innovative online learning and fun for students. Efforts that must be made are to collaborate with education service providers to provide training on the utilization, strategies, models and methods of online learning that are appropriate and meet the needs of teachers by improving facilities and infrastructure to support online learning. (2) The implementation of online learning should be carried out in a short time and the material to be delivered is more concise, clear, varied, and fun by using language that is easily understood by students so that it can minimize wasteful spending on internet quota and make students to stay concentrate in following the lesson. The Problem Based Learning model can be used by the teacher as an alternative model to increase the involvement and activeness of students in the implementation of online learning. (3) The types of assignments to be given during the Covid-19 pandemic must vary so that students are interested in doing them. The quantity of the assignment needs to be considered so as not to burden students in doing it and the assignment instructions need to be conveyed more clearly. The teacher can give assignments such as making a modification of sports equipment using materials that can be used and easily found at home as well as assignments that involve the family in completing their tasks.

\section{References}

A.D.W., L. (2014). Dimensi Olahraga Pendidikan Dalam Pelaksanaan Penjasorkes Di Sekolah. Jurnal Pendidikan Olah Raga.

Ali, S., \& Hamidah, A. (2020). Pembelajaran Daring di Tengah Wabah Covid-19. Jurnal Ilmiah Pendidikan Biologi, 6(02), 214-224.

COVID 19, G. T. (2020). Data Sebaran.

Firman, \& Rahman, S. R. (2020). Pembelajaran Online di Tengah Pandemi Covid-19. Indonesian Journal of Educational Science (IJES), 2(2), 81-89.

Henry, R. A. (2020, Juli). KENDALA PEMBELAJARAN DARING GURU SEKOLAH DASAR DI KABUPATEN BANJARNEGARA. 7(2), 297-302.

Husamah. (2015). Pembelajaran Bauran (Blended Learning). Jakarta.

Indonesia, S. E. (2019). Penyederhanaan Rencana Pelaksanaan Pembelajaran.

Jamrah, A. (2016). SHAPING GOLDEN GENERATION THROUGH CHARACTER. Proceeding International Seminar on Education, 41-50.

Kasriman. (2016). EVALUASI PROGRAM PEMBELAJARAN PENDIDIKAN JASMANI PADA SEKOLAH DASAR NEGERI DI KECAMATAN DUREN SAWIT, JAKARTA TIMUR . 365-382.

Kastrena, E., Setiawan , E., Patah , I. A., \& Nur, L. (2020). Pembelajaran Peer Teaching Berbasis Zoom Video sebagai Solusi untuk Meningkatkan Hasil Belajar Passing Bawah Bola Voli saat Situasi Covid 19. Indonesian Journal of Primary Education, 4(1), 69-75.

Kebudayaan, M. P. (2020). SURAT EDARAN NOMOR 4 TAHUN 2O2O TENTANG PELAKSANAAN KEBIJAKAN PENDIDIKAN DALAM

PJKR

https://jurnal.unimed.ac.id/2012/index.php/jpehr 
MASA DARURAT PENYEBARAN CO RO NAVIRU S D/SEASE (COVID- 19 ).

Kemendikbud. (2017). Panduan Penilaian oleh Pendidik dan Satuan Pendidikan untuk Sekolah Menengah Pertama.

Khasanah, D. R., Pramudibyanto, H., \& Widuroyekti, B. (2020, April). Pendidikan Dalam Masa Pandemi Covid-19. Jurnal Sinestesia, 10(1), 41-48.

Negeri, K. P. (2020). PANDUAN PENYELENGGARAAN PEMBELAJARAN PADA TAHUN AJARAN DAN TAHUN AKADEMIK BARU DI MASA PANDEMI CORONA VIRUS DISEASE (COVID-19).

NEGERI, K. P. (2020). PANDUAN PENYELENGGARAAN PEMBELAJARAN PADA TAHUN AJARAN DAN TAHUN AKADEMIK BARU DI MASA PANDEMI CORONA VIRUS DISEASE (COVID-19).

Permendikbud. (2016). Standar Proses Pendidikan Dasar dan Menengah.

Purwanto, A., Prawono, R., Asbari, M., Santoso, P. B., Wijayanti, L. M., Hyun, C. C., et al. (2020). Studi Eksploratif Dampak Pandemi COVID-19 Terhadap Proses Pembelajaran Online di Sekolah Dasar . Edupyscon Journal, 1-12.

Rachmat , A., \& Krisnadi , I. (2020). ANALISIS EFEKTIFITAS PEMBELAJARAN DARING (ONLINE) UNTUK SISWA SMK NEGERI 8 KOTA TANGERANG PADA SAAT PANDEMI COVID 19 . 1-7.

Reza, P. M. (2020). Kendala Pelaksanaan Pembelajaran Jarak Jauh (PJJ) dalam Masa Pandemi. Pendidikan Vokasional Konstruksi Bangunan, 1-6.

Rumbo, S. S. (2020). China dan Pandemi Covid-19. Kompas Pedia.

Szpunar, K. K., Moulton, S. T., \& Schacter, D. L. (2013). Mind wandering and education: from the classroom to online learning. Frontiers in Phychology, 4, 495.

Utama, A. B. (2011, April ). PLAY AS THE INITIAL CHARACTER HABITUATION OF CULTURE IN EARLY CHILDHOOD. Pendidikan Jasmani Indonesia, 8(1), $1-10$.

Yezli, S., \& Khan, A. (2020). COVID-19 social distancing in the Kingdom of Saudi Arabia: Bold measures in the face of political, economic, social and religious challenges. Travel Medicine and Infectious Disease , 1-4.

Yuniartik , H., Hidayah , T., \& Nasuka . (2017). Evaluasi Pembelajaran Pendidikan Jasmani Olahraga dan Kesehatan di SLB C Se-Kota Yogyakarta. Journal of Physical Education and Sports, 6(2), 148 - 156.

Zuharon, Y. (2017). KEMAMPUAN GURU PENJAS DALAM PROSES PEMBELAJARAN PENJAS SEKOLAH DASAR NEGERI SE KECAMATAN NGEMPLAK KABUPATEN SLEMAN. 1-9. 